\title{
Does mood affect institutional herding?
}

\author{
Konstantinos Gavriilidis ${ }^{\mathrm{a}}$, Vasileios Kallinterakis ${ }^{\mathrm{b}, *}$ and Belma Öztürkkal ${ }^{\mathrm{c}}$
}

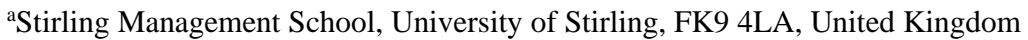

bUniversity of Liverpool Management School, Chatham Building, Chatham Street, Liverpool L69 7ZH, United Kingdom cKadir Has University, Department of International Trade and Finance, Kadir Has Caddesi Cibali, Istanbul 34083, Turkey

\begin{abstract}
Drawing on a unique data set of daily portfolio holdings for Turkish mutual funds we investigate the relationship between mood and institutional herding on the premises of various established mood proxies (weekend effect; holiday effect; Ramadan; sunshine). Results indicate that fund managers in Turkey herd significantly, with their herding growing in magnitude as the number of active funds per stock rises and appearing stronger on the buythan the sell-side. Although the relationship of mood with institutional herding occasionally assumes the correct sign as per theoretical expectations, institutional herding is found to be insignificantly different across various mood states, thus denoting that mood does not impact the propensity of fund managers to herd.
\end{abstract}

Keywords: herding; mood; fund managers; Turkey

JEL Classification: G15; G23; G40; G41

Acknowledgements: The authors would like to thank Mr Hüseyin Uzer from the Capital Markets Board of Turkey for kindly assisting us with the provision of the database utilized in the paper.

* Corresponding author. Email: V.Kallinterakis@ liverpool.ac.uk 


\section{Introduction}

Institutional investors constitute by far the most dominant investor group in contemporary financial markets, accounting for the bulk of the market capitalization and trading volume of the latter (Choi and Sias, 2009; Stambaugh, 2014). Although their sophisticated nature would presume the prevalence of rationality in their trades, international evidence suggests their particular susceptibility to behaviourally biased trading patterns ${ }^{1}$, the most widely documented of those being herding. ${ }^{2}$ Extant research has denoted the importance of several rational factors underlying the propensity of institutional investors to herd, including informational asymmetries (Gelos and Wei, 2005; Choi and Skiba, 2015), career concerns (Holmes et al., 2013; Jiao and Ye, 2014), style investing (Sias, 2004; Choi and Sias, 2009; Celiker et al., 2015) and their regulatory framework (Voronkova and Bohl, 2005), to mention but a few. However, the effect of mood (a less-than-perfectly rational factor) over institutional herding has not been investigated to date despite the recent surge in research (Goetzmann et al., 2015; Kaustia and Rantapuska, 2016) on mood's impact over the trading behaviour of institutional investors and it is this issue that this study aims at addressing.

More specifically, we investigate the relationship between mood and institutional herding in the context of the Turkish equity market drawing on a unique database of daily portfolio holdings of the market's domestic funds. Utilizing various established mood proxies (weekend effect; holidays; Ramadan; sunshine) this research addresses two specific issues. First, we examine whether various mood states are related to the presence of institutional herding (i.e. its statistical significance), in general. Second, in view of literature evidence (Kamstra et al., 2003) on the propensity of mood to affect the direction of investors' trades, we assess whether

\footnotetext{
${ }^{1}$ Such as momentum trading (Choi and Skiba, 2015) and the disposition effect (Jin and Scherbina, 2011).

${ }^{2}$ See e.g. the recent global empirical evidence by Choi and Skiba (2015).
} 
these mood states are associated with the direction of institutional herding (i.e. whether it is buy- or sell-herding that is observed during their occurrence).

Overall, we produce results showcasing the presence of significant herding among Turkish fund managers whose magnitude increases with the number of active funds per stock and which appears stronger on the buy- than the sell-side. As regards the relationship between mood and institutional herding presence, our results confirm it is insignificant. We report evidence in support of funds herding more on Mondays, during Ramadan and on days of decreased sunshine, without however that herding being significantly different from that manifested on Fridays, outside Ramadan and on days of increased sunshine, respectively; results further suggest the presence of some pre holiday herding.

Turning now to the relationship between mood and institutional herding direction, we find Ramadan-days presenting us with evidence of buy-herding only (which - for those cases when it is present - is always stronger, compared to that of non-Ramadan days), while sell-herding appears exclusively present outside Ramadan. What is more, buy- (sell-) herding is stronger on increased (decreased) sunshine days; buy-herding appears stronger compared to sell-herding on increased sunshine days, while decreased sunshine days present us with no consistent pattern on whether it is buy- or sell-herding that is stronger for them. Evidence of buy-herding for Mondays and Fridays is rather limited (surfacing relatively more on Mondays than Fridays), with its magnitude being larger for Mondays compared to Mondays' sell-herding (for those cases where both buy- and sell-herding are significant on Mondays). Conversely, sell-herding appears consistently present on Fridays and always stronger than sell-herding on Mondays (when the latter is present). However, aside from a few exceptions (identified mainly with some significant herding differences between Mondays and Fridays) most differences in both buyand sell-herding are statistically insignificant for various mood states, indicating that mood bears no significant relation to institutional herding direction. 
We further test for the robustness of our results by performing a series of tests. First, we repeat all estimations excluding tracker funds (whose trades are, by definition, motivated by benchmark-tracking) from the sample and report results near-identical to those from the fullsample estimations. Second, we control for possible size effects by sorting stocks in quintiles based on previous-year market capitalization rankings; results again indicate that institutional herding is insignificantly different across various mood states irrespective of stock-size (and appearing the least strong for stocks of the lowest capitalization).

Our work contributes significantly to behavioural finance research in distinct ways. To begin with, it assesses the relationship between mood and institutional herding for the first time in the literature and produces evidence suggesting that this relationship is insignificant, thus denoting that mood states do not significantly bias the propensity of sophisticated investors to herd. Compared to extant research on mood effects over institutional trading behaviour, the evidence we present in this study is in line with the findings reported by Kaustia and Rantapuska (2016) on the weak effect of weather-related mood proxies over the trading behaviour of institutional investors in Finland, yet runs counter to Goetzmann et al. (2015) who find that cloud cover affects mispricing perceptions and trading decisions of US fund managers. Second, our findings suggest that the pursuit of a behaviourally biased trading pattern (in our case, herding) by fund managers does not necessarily render them susceptible to mood effects in their trading. Third, given that mood as a factor is far from strictly rational, we contribute to the research on the effect of less-than-perfectly rational factors over market herding in general (Chang and Lin, 2015; Eun et al., 2015), and institutional herding in particular (Beckmann et al., 2008; Liao et al., 2011; Celiker et al., 2015). ${ }^{3}$

\footnotetext{
${ }^{3}$ Although earlier research (Gavriilidis et al., 2016) explored the role of social mood (proxied via Ramadan) in market-wide herding, no research exists on the link between mood per se and institutional herding.
} 
Our study bears important implications for researchers, as it highlights the need for a more comprehensive investigation of the relationship between mood and institutional herding at a wider cross market level internationally, in order to establish whether it reveals any patterns and whether it varies among markets at different stages of financial development. It would be interesting, for example, to gauge whether mood-factors common to several countries (such as, for example, the Ramadan month in majority Muslim countries) produce similar effects over their funds' herding. Another possibility would be to investigate whether, herding aside, mood is related to other behavioural investment patterns popular among fund managers, such as momentum trading (Choi and Skiba, 2015). As far as the wider investment community is concerned, the emergence of any mood-related patterns in the herding of fund managers would suggest the potential for those patterns motivating ad hoc trading strategies. If, for example, a significant relationship between a weather mood-proxy (e.g. sunshine) and institutional herding were to be established, one could trade in/against the anticipated direction of funds' herding given that proxy's forecasts while at the same time hedge their position via weather derivatives (whose popularity as hedging instruments since the mid-1990s would render such a strategy theoretically feasible; see, for example, Pérez-González and Yun, 2013).

The rest of the paper is structured as follows: section 2 provides an overview of herd behaviour and its key sources (section 2.1), introduces mood as a concept (section 2.2) and discusses the theoretical relationship between herding and mood (section 2.3). Section 3 presents the dataset utilized (section 3.1) and outlines the empirical design employed, alongside a discussion of the mood-proxies controlled for (section 3.2). Section 4 discusses the results and section 5 concludes.

\section{Theoretical foundations}

\subsection{Herding}


From a conceptual perspective, herding refers to the situation whereby investors exhibit similarity in their behaviour following interactive observation of each other's actions or actionpayoffs, while at the same time sidelining their private information or fundamentals (Hirshleifer and Teoh, 2003). Institutional herding can give rise to issues regarding funds' portfolio structures, in terms of the efficiency of their allocation and their congruence to their clients' risk preferences (Economou et al., 2015), in effect raising the possibility of moral hazard in their industry. What is more, the dominance of institutional investors in modern financial markets and the increasingly globalized financial environment in which they operate imply that any herding on their behalf is capable of fomenting new and exacerbating existing financial episodes, both within and across markets, thus contributing to systemic risk. As a general observation, institutional herding is widely documented internationally (Choi and Skiba, 2015), with research (Holmes et al., 2013; Gavriilidis et al., 2013) suggesting that fund managers herd either intentionally (in anticipation of a benefit) or spuriously (due to a common factor fostering correlation in their trades). Fund managers herd intentionally as a response to (actual or perceived) asymmetries in the market environment which prompt some of them to view themselves as disadvantaged; in this case, mimicking the behaviour of their ("better") peers offers them the opportunity to improve their position. Such asymmetries could be informational (managers whose quality of information or information processing skills are low, are tempted to track the trades of their better informed peers in order to free ride on their information; Banerjee, 1992, Bikhchandani et al., 1992) as well as reputational (less able/reputed investment professionals may choose to mimic their better-quality peers to improve their professional image and ensure that their low quality is not detected; Scharfstein and Stein, 1990). ${ }^{4}$ On the other hand, fund managers herd spuriously when their trades exhibit

\footnotetext{
${ }^{4}$ This is particularly important during down markets, since the higher likelihood of losses during the latter entails graver professional implications for fund managers. Should a "bad" manager choose to mimic a "good" one's trades during a down market period, he could claim his trading decisions were prudent (they would tally with those of "good" managers) and attribute any losses to the prevailing adverse market conditions. Reputational
} 
similarity due to the influence of a common factor to which they are all exposed, without interactive observation among them being present. Key to spurious herding is relative homogeneity, the latter referring to features common among managers which lead to similarities in their decisions (De Bondt and Teh, 1997); such features can include, for example, the similar educational backgrounds and professional qualifications of most fund managers, the similarities in the selection and processing of micro/macro indicators (Wermers, 1999) and their regulatory framework (Voronkova and Bohl, 2005; Blake et al., 2017). Spurious herding can also be motivated via style investing ("characteristic trading"; Sias, 2004), the latter referring to strategies involving stock selection based on specific stock characteristics, such as past performance, value and industry. Style investing is particularly popular among institutional investors and, if a sufficiently large number of them follow a given style, this can lead them to trade similarly, generating the impression of them herding.

\subsection{Mood}

Conceptually, mood constitutes a pre rational state of affective content experienced internally by an individual and motivated by both exogenous (e.g. environmental conditions), as well as endogenous (such as a person's earlier emotional experiences) factors (Frijda, 1993). Moodstates can be both global (e.g. positive versus negative mood) as well as specific (e.g. euphoria versus anger) and are of a transient nature, thus constituting short-lived phenomena (Frijda, 1993) with no conscientious cognitive effort mediating their appearance and evolution. Mood can be perceived individually (a person who has just lost a loved one will experience feelings of loss) as well as collectively (a natural disaster befalling a city will induce negative emotions

considerations, can, however, promote similar behaviour during market upswings as well, since underperforming during up markets would only help cast a professional stigma over a "bad" manager. 
to its inhabitants). The impact of mood can be felt in various cognitive functions, including attention, encoding of information, forecasting, memory, motivation and perception, thus being expected to be present in individuals' judgement-formation and decision-making (Isen, 2000). The onset of a given mood tends to prompt mood-congruent cognitive processes and decisions (Schwarz, 2002); a person in a positive mood is likely to view the world as a better place (a person with negative mood will probably not) and a happy (sad) person will be more (less) likely to enter risky decisions.

In the context of financial markets, mood has been associated with the promotion of moodcongruent perceptions of risk and direction of investors' trades. Positive mood tends to reduce an investment's perceived riskiness, prompting people to be less averse towards engaging in it and rendering them more likely to resort to heuristics in its analysis (its lower perceived riskiness reduces the necessity for analytical processing; Schwarz, 1990, Forgas, 1998), with people in a negative mood tending to view investments as riskier than they actually are and devoting more time in trying to detect their possible pitfalls (Schwarz, 2002). Therefore, investors in a positive (negative) state of mood would be expected to be more (less) overconfident (Au et al., 2003), engage in more (less) risk-seeking behaviour (Forgas, 1995; Isen, 2000; Kuhnen and Knutson, 2011; Bassi et al., 2013) and view equity investing as an opportunity (a threat), thus being more likely to buy (sell) stocks (Mittal and Ross, 1998). ${ }^{5}$

Drawing on a wide array of mood-proxies, including sunshine (Hirshleifer and Shumway, 2003), temperature (Cao and Wei, 2005), biorhythms (Kamstra et al., 2003), holidays (Meneu

\footnotetext{
${ }^{5}$ A term often used interchangeably with mood (despite it not entailing the same content) is "sentiment" (Baker and Wurgler, 2007); the latter pertains to extrapolative beliefs about future cash flows and risks, based on the perception of a trend being at works (e.g. that an up/downward trend in earnings will persist). Unlike mood, sentiment is "fundamentals-plus", in the sense that the beliefs underlying it are founded on existing fundamentals which are then extrapolated upon to project future trends. Furthermore, unlike mood, sentiment involves cognitive effort (its formulation merits some processing of the information available) and tends to be of longer duration (as it relates to wider market trends). Additionally, whereas mood bears no causal relationship to economic/financial indicators (stock returns, for example, do not cause changes in sunshine levels), sentiment does (it can be reflected through e.g. consumer confidence indices, IPOs' first-day returns and trading volume).
} 
and Pardo, 2004), religious celebrations (Białkowki et al., 2012), sports events (Edmans et al., 2007), aviation disasters (Kaplansky and Levy, 2010) and terrorist attacks (Brounen and Derwal, 2010), research has denoted that events/situations with positive (negative) emotional content are associated with positive (negative) average equity returns. Recent research has also examined the role of mood in institutional investors' trades, without the evidence produced appearing conclusive; Goetzmann et al. (2015) found cloud cover to affect US fund managers' equity valuations and trade-direction (more (less) cloud cover increased (decreased) their perceived overpricing of stocks and prompted them to buy less (more)), while Kaustia and Rantapuska (2016) reported weak effects of various weather-related mood proxies over Finnish funds' trades. ${ }^{6}$

\subsection{Mood and herding}

Whereas the above mentioned (section 2.1) intentional and spurious herding factors are rational in nature and their role in institutional herding has been widely investigated (see the survey evidence in Hirshleifer and Teoh, 2003 and Spyrou, 2013), little is known about the role of less-than-perfectly rational factors in this regard. ${ }^{7}$ To that end, in this section we shall delineate the context of the relationship between mood and herding, in order to provide our study with a theoretical foundation. The key starting point here is that investment decisions entail high complexity and uncertainty and, as such, merit the substantial commitment of resources, including time and cognitive deliberation (Lucey and Dowling, 2005). However, deliberation on a topic is forced to compete for mental resources and attention with other tasks that need to

\footnotetext{
${ }^{6}$ Kaustia and Rantapuska (2016) also report weak weather-related mood effects over Finnish retail investors' trades. Goetzmann and Zhu (2005) find that cloud cover does not affect US retail investors' trades, while Schmittmann et al. (2015) show that German retail investors buy (trade) more when the weather is good (bad).

${ }^{7}$ With the exception of a few studies exploring the role of culture (Beckmann et al., 2008) and sentiment (Liao et al., 2011; Celiker et al., 2015) on institutional herding, we are aware of no other studies investigating the role of such factors over the propensity of fund managers to herd.
} 
be cognitively processed, thus ending up being neurologically taxing for the brain (Ardalan, 2018). This raises issues regarding the costs and benefits of deliberation, the result being that, when faced with several options, humans are likely to end up choosing a "satisficing" one (e.g. the least costly option) rather than the optimal one (Lucey and Dowling, 2005).

It is in this context of satisficing that mood enters investment decision-making; as Forgas (1995) has illustrated, the more (less) complex a decision is, the greater (lesser) the influence of feelings on it would be expected to be. This is of key relevance to investment decisions, considering their innate uncertainties and was further expounded by Loewenstein et al. (2001), whose "risk-as-feelings" model showcased that cognitive decisions involving risk and uncertainty are both motivated by and culminate into emotional responses. An issue arising in this context pertains to identifying the origins of those emotions and the relevant literature has come up with two possibilities in this respect. On the one hand, we have emotions exogenous (originating in environmental factors, such as weather, temperature and social interaction) to the decision-making process that affect judgement by prompting mood effects on fundamentally irrelevant decisions (e.g. the case where individuals' perceptions of their lifesatisfaction are influenced by whether the weather at the time of their questioning is sunny or overcast; Schwarz and Clore, 1983). In this case, affective states are misattributed for information in the decision-making process (they nudge individuals towards reaching a decision based on how they feel about it) and this has come to be known as mood-misattribution (see e.g. Goetzmann et al., 2015). On the other hand, emotions may well hail from factors endogenous to the decision-making process itself, such as for example the image of a decision's underlying object (e.g. a stock or a sector; Taffler, 2018).

Whatever the source of emotions may be, the mood infused by them leads individuals to temporarily - suspend rational processing in their cognitive evaluations, in effect increasing the likelihood of heuristics dominating decision-making and this is where the foundations for 
the mood-herding link lie. Since herding constitutes a heuristic in itself ${ }^{8}$ and given that it grows stronger under conditions of uncertainty ${ }^{9}$ (when one would expect emotions to exert considerable influence), it is entirely plausible to assume that herding can be unconsciously encouraged by the prevailing mood among investors. ${ }^{10}$ This is particularly expected to be the case in the presence of positive mood, which has been found (Schwarz, 1990; Forgas, 1998) to reduce the perception of risk in decisions (hence, decrease risk-aversion) and render the employment of heuristics more likely in their processing. Evidence in support of herding during positive mood periods has been furnished regarding positive mood hailing both from exogenous (environmental) factors (the case of the Ramadan-celebration; Gavriilidis et al., $2016^{11}$ ) as well as endogenous ones (the case, for example, of the Dot Com bubble). ${ }^{12}$ However, although negative mood is assumed to prompt investors to view decisions as riskier than they actually are (hence, increase risk-aversion) and resort to more analytical processing (Schwarz, 1990), this does not necessarily suggest the absence of heuristics under negative affective states. This is because any analytical decision-making will inevitably involve deliberation costs, which, beyond a certain threshold, will prompt the individual to switch to heuristics to automate the cognitive evaluation. Therefore, it is not unlikely that, in the presence of negative mood, investors will choose to herd with their peers, if the complexity of a decision renders deliberating on it prohibitively expensive. This is expected to be further enhanced via the riskaversion and loss-avoidance typifying periods of negative affective content. If, for instance, progressively worsening market conditions (e.g. an evolving crisis) amplify negative mood in

\footnotetext{
${ }^{8}$ This is the case particularly with intentional herding, whereby investors faced with e.g. an informational problem choose to mimic their better-informed peers rather than attempt to tackle it themselves.

${ }^{9}$ Evidence, for example, suggests that investors herd the strongest when their investments are of high-risk, such as stocks of small capitalization (Lakonishok et al., 1992; Wermers, 1999; Sias, 2004) or stocks from emerging/frontier markets (Economou et al., 2015; Guney et al., 2017).

${ }^{10}$ This is the case of social mood promoting herding via social interactions among investors, a possibility that was explored in earlier research (Olson 2006).

${ }^{11}$ The authors showed that market herding in majority Muslim stock exchanges was stronger during, compared to outside, Ramadan.

${ }^{12}$ See Brunnermeier and Nagel (2004), Griffin et al. (2011) and Singh (2013) for more on herding during that bubble.
} 
the market, it is more likely that investors will unload their positions in tandem with their peers to curtail their losses, rather than invest time on analysing the causes, effects and likely duration of the crisis.

The above discussion denotes that herding can interact significantly with mood and be motivated by both positive and negative affective states, with its presence expected to be more pronounced during positive mood periods (as it is those that foster heuristic-based assessments in decision-making). Although our study investigates herding among fund managers, who are presumed to be sophisticated and rational and who, as a result, would be assumed to be in no need of imitating their peers, the notably extensive literature on institutional trading suggests that herding among them is both present and of high magnitude. ${ }^{13}$ It follows, therefore, that the possibility of their herding accommodating mood-effects cannot be precluded, more so in view of the mixed recent evidence (Goetzmann et al., 2015; Kaustia and Rantapuska, 2016) on mood-effects over institutional trades.

\section{Data and methodology}

\subsection{Data}

We test empirically for the effect of mood over institutional herding on the premises of a unique data set entailing the daily portfolio holdings of all "Type A" Turkish funds active during the period between January $2^{\text {nd }}, 2002$ and August $14^{\text {th }}, 2008 .{ }^{14}$ Funds formally designated as "Type A" are required by law to invest at least $25 \%$ of their portfolio assets in domestic equities (with

\footnotetext{
${ }^{13}$ For more on this, see Sias (2004), Choi and Sias (2009), Choi and Skiba (2015) and Jiang and Verardo (2018).

${ }^{14}$ No daily data on Turkish funds' portfolio holdings was available outside that window.
} 
funds not subject to said requirement designated as "Type B"15). ${ }^{16}$ The database was obtained from the Capital Markets Board of Turkey and includes information on the: code and name of each fund; code and name of each asset in each fund's portfolio; end-of-day number of units, price and market value (all expressed in Turkish Lira) of each asset held. The advantage of using daily portfolio holdings to test whether funds herd due to mood effects rests on the fact that mood is a short term phenomenon (Frijda, 1993) and using daily funds' data enables us to better track any effects of mood changes over their herding.

As the descriptive statistics presented in Table 1 illustrate, our sample comprises of all 134 "Type A" funds active at any point during our sample period, a fact which allows our sample to be free from survivorship bias; these funds invested in a total of 419 domestic stocks throughout that period. Of those 134 funds, 35 are equity funds, 21 are balanced/mixed funds, 64 are variable funds ${ }^{17}$ and 14 are index funds. The average number of active stocks per day traded by at least one fund is 75 (or approximately $18 \%$ of the total number of stocks our sample funds invested in during the sample period), with the average number of active funds per stock per day being 3 . When looking at the corresponding figures for stocks traded by at least 2,3 and 4 funds, we notice that the average number of stocks per day actively traded by funds falls substantially (reaching only 23 stocks for stocks traded by at least 4 funds), while the average number of active funds per stock per day for stocks traded by at least 4 funds is 7 . Overall, these figures indicate a rather concentrated daily equity trading activity on behalf of "Type A" funds in the Turkish stock market that clearly has the potential of encouraging herding; with 3-

\footnotetext{
15 “Type B" funds' portfolios are dominated by fixed income instruments, such as bonds and repos.

${ }^{16}$ Both fund-types are open-ended; they are not allowed to hold more than $9 \%$ of the total shares outstanding of any company and are also not allowed to invest more than $10 \%$ of their net asset value in any company's shares. 17 Variable funds are funds which, aside from the 25\%-threshold on equity investments pertaining to "Type A" funds mentioned above, are not subject to any further restrictions on their portfolio allocation.
} 
7 funds, on average, being active per stock each day, this helps facilitate observation among them, thus rendering herding more feasible - and likely.

\subsection{Methodology}

To measure institutional herding - and later assess its relationship with mood - we employ the measure proposed by Sias (2004), which aims at extracting herding via the intertemporal dependence in the structure of institutional demand for stocks; more formally, institutional demand is proxied via the raw fraction of funds buying stock $k$ in period (in our case, day) $t$ $\left(\operatorname{Raw} \Delta_{\mathrm{k}, \mathrm{t}}\right)$, which is calculated as:

$\operatorname{Raw} \Delta_{\mathrm{k}, \mathrm{t}}=\frac{\text { Number of funds buying stock } \mathrm{k} \text { on day } t}{\text { Total number of funds active in stock } k \text { on day } t}$

The total number of active funds in the denominator of Equation (1) is the sum of all funds that have either increased ("buyers") or decreased ("sellers") their position in stock $k$ on day $t$ compared to day $t-1$. Raw $\Delta_{\mathrm{k}, \mathrm{t}}$ is then standardized by subtracting on each day from each stock's $\operatorname{Raw} \Delta_{\mathrm{k}, \mathrm{t}}$ its cross sectional (across all active stocks on that day) mean $\left(\overline{\operatorname{Raw} \Delta_{\mathrm{t}}}\right)$ and dividing it by its cross sectional standard deviation $\left(\sigma\left(\operatorname{Raw} \Delta_{\mathrm{k}, \mathrm{t}}\right)\right)$ :

$\Delta_{\mathrm{k}, \mathrm{t}}=\frac{\operatorname{Raw} \Delta_{\mathrm{k}, \mathrm{t}}-\overline{\operatorname{Raw} \Delta_{\mathrm{t}}}}{\sigma\left(\operatorname{Raw} \Delta_{\mathrm{k}, \mathrm{t}}\right)}$

To assess the temporal dependence of institutional demand, Sias (2004) proposed a first order autoregressive structure for $\Delta_{\mathrm{k}, \mathrm{t}}$, as follows:

$\Delta_{\mathrm{k}, \mathrm{t}}=\beta_{\mathrm{t}} \Delta_{\mathrm{k}, \mathrm{t}-1}+\varepsilon_{\mathrm{k}, \mathrm{t}}$

With both sides of Equation (3) being standardized (and since $\Delta_{\mathrm{k}, \mathrm{t}-1}$ is its sole independent variable), its slope $\left(\beta_{t}\right)$ represents the cross sectional correlation of institutional demand between day $t$ and day $t$-1. Sias (2004) then partitioned $\beta_{t}$ as follows: 


$$
\begin{aligned}
& \beta_{t}=\rho\left(\Delta_{k, t}, \Delta_{k, t-1)}=\right. \\
& {\left[\frac{1}{(K-1) \sigma\left(\operatorname{Raw}_{k, t}\right) \sigma\left(\operatorname{Raw}_{k, t-1}\right)}\right] x \sum_{k=1}^{K}\left[\sum_{n=1}^{N} \frac{\left(D_{n, k, t}-\overline{\operatorname{Raw} \Delta_{t}}\right)\left(D_{n, k, t-1}-\overline{\operatorname{Raw} \Delta_{t-1}}\right)}{N_{k, t} N_{k, t-1}}\right]} \\
& +\left[\frac{1}{(K-1) \sigma\left(\operatorname{Raw}_{k, t}\right) \sigma\left(\operatorname{Raw}_{k, t-1}\right)}\right] x \sum_{k=1}^{K}\left[\sum_{n=1}^{N} \sum_{m=1, t, m \neq n}^{N_{k, t-1}} \frac{\left(D_{n, k, t}-\overline{\operatorname{Raw} \Delta_{t}}\right)\left(D_{m, k, t-1}-\overline{\operatorname{Raw} \Delta_{t-1}}\right)}{N_{k, t} N_{k, t-1}}\right]
\end{aligned}
$$

In the above equation, the first additive component represents the part of the slope due to funds following their own lagged trades and the second one the part of the slope due to funds following the lagged trades of other funds (herding). Positive (negative) values for the first component would suggest that funds trade on day $t$ in (against) the direction of their trades in day $t-1$; positive (negative) values for the second component would indicate that funds on day $t$ trade toward (away from) other funds' trades of day $t-1$. From the perspective of notation, $\mathrm{N}_{\mathrm{k}, \mathrm{t}}$ is the total number of active funds in stock $k$ on day $t, \mathrm{D}_{\mathrm{n}, \mathrm{k}, \mathrm{t}}$ is a dummy variable assuming the value of unity (zero) if fund $n$ increases (decreases) its position in stock $k$ on day $t$ and $\mathrm{D}_{\mathrm{m}, \mathrm{k}, \mathrm{t}-1}$ is a dummy variable assuming the value of unity (zero) when fund $m(m \neq n)$ increases (decreases) its position in stock $k$ on day $t-1$.

Since we investigate the effect of mood not only over institutional herding presence but also its direction, we account for the latter by partitioning our sample stocks each day into two groups (see Holmes et al., 2013), a buy-herd (comprised of stocks predominantly bought, i.e. whose $\operatorname{Raw} \Delta_{\mathrm{k}, \mathrm{t}}>0.5$ ) and a sell-herd (comprised of stocks predominantly sold, i.e. whose $\left.\operatorname{Raw} \Delta_{\mathrm{k}, \mathrm{t}}<0.5\right)$ one and estimate the Sias (2004) measure for each.

We investigate the relationship between mood and institutional herding by assessing the interactions of the latter with four mood-proxies (weekend effect; holidays; Ramadan; sunshine) which have been established as such in the literature and we shall now briefly discuss the mood effects associated with each. 
Weekend effect: this is one of the oldest documented effects in finance (see, for example, the discussion in Lakonishok and Smidt, 1988) and refers to stock returns being, on average, negative on Mondays and rising as one moves from Tuesday to Friday (with Friday's returns being the highest of the week). Despite the wealth of rational explanations proposed to account for it, a significant number of studies have attributed the effect to investors' mood being negative on Mondays ("Monday Blues") ${ }^{18}$ and the most positive on Fridays. ${ }^{19}$ With respect, specifically, to institutional investors, who constitute the focus of our study, evidence on the connection of their trades to the weekend effect is rather mixed (see the discussion in Morse et al., 2014). We test empirically for the weekend effect by partitioning $\beta_{\mathrm{t}}$ and its two components (funds following their own trades; funds following the trades of other funds) into two groups corresponding to Mondays and Fridays, respectively.

Holiday effect: empirical research (see Meneu and Pardo, 2004 for a comprehensive review) has shown that pre holiday returns are significantly positive and account for a considerable portion of each year's total rate of return, with post holiday returns having been found to be insignificantly different from average ordinary day returns. Considering that holidays allow individuals the opportunity for relaxation via distraction from their daily routine and are associated with a sense of euphoria (Lahav et al, 2016), it has been suggested (Fabozzi et al, 1994) that the abnormally high pre holiday returns are motivated by investors' positive mood prior to a holiday. The holiday effect is similar to the weekend effect, since both involve a trading break (weekend; holiday), with people's mood being positive in anticipation of it on its eve (Friday; pre holiday) and reversing (Monday) or dissipating (post holiday) on the day following it. We test empirically for the holiday effect by first identifying the major national

\footnotetext{
18 "Monday-Blues" here refer to the negative mood induced on Mondays due to the change in sleep patterns between the weekend and Monday (Kramer, 2001).

${ }^{19}$ For a review of research on rational and mood-related explanations of the weekend effect see Birru (2016).
} 
and religious holidays of the Republic of Turkey $^{20}$ and then partitioning $\beta_{\mathrm{t}}$ and its two components (funds following their own trades; funds following the trades of other funds) into two groups corresponding to pre holiday and post holiday days, respectively.

Ramadan: it is the ninth month of the Islamic calendar, central to which is the requirement for Muslims to engage in prayers, fast during day light and refrain from smoking and sensual pleasures (Białkowski et al., 2012). Ramadan's atmosphere is characterized by spiritual elation and positive mood (Gavriilidis et al., 2016), culminating in a common euphoric state of religion-induced experience to which individuals in majority Muslim countries are collectively subject. This, in turn, promotes relative homogeneity of an emotional content in society (Gavriilidis et al., 2016), which, coupled with the enhanced social interaction levels observed during that month (Białkowski et al., 2012), increase the potential for commonality in behaviour. We test for the relationship between Ramadan and institutional herding by first identifying (based on the approach of Białkowski et al., 2012) the Ramadan months during our sample period (2/1/2002 - 14/8/2008) and then partitioning $\beta_{\mathrm{t}}$ and its two components (funds following their own trades; funds following the trades of other funds) into two groups corresponding to within and outside Ramadan, respectively.

Sunshine: a large volume of research (see Goetzmann et al., 2015 for an overview) has confirmed the effect of sunshine over mood and the effect's implications for medical science; all in all, sunshine has been found to boost mood, whereas overcast weather tends to dampen it. In the financial context, research to date has investigated the effect of sunshine over equity returns (Saunders, 1993; Hirshleifer and Shumway, 2003), risk tolerance (Bassi et al., 2013) and investors' trading behaviour (Goetzmann and Zhu, 2005; Goetzmann et al., 2015; Schmittmann et al., 2015; Kaustia and Rantapuska, 2016). Although the evidence presented is

\footnotetext{
${ }^{20}$ These are: New Year (January $1^{\text {st }}$ ), Children's Day (April $23^{\text {rd }}$ ), Labour Day (May $1^{\text {st }}$ ), Youth and Sports Day (May 19 $9^{\text {th }}$ ), Victory Day (August $30^{\text {th }}$ ), Republic Day (October $29^{\text {th }}$ ), Kurban Bayrami and Ramazan Bayrami.
} 
not necessarily consistent, sunshine, generally, tends to be associated with positive returns in equity markets and a stronger buy-propensity on behalf of investors. We test empirically for the relationship between sunshine and institutional herding presence/direction in our study by identifying the hours of sunshine every day during our sample period $(2 / 1 / 2002-14 / 8 / 2008)$ utilizing data from the Turkish State Meteorological Service, ${ }^{21}$ we then partition $\beta_{\mathrm{t}}$ and its two components (funds following their own trades; funds following the trades of other funds) into two groups corresponding to days of increased and days of decreased sunshine, respectively, contingent on whether day $t$ entails more or fewer hours of sunshine compared to day $t-1$.

We now turn to discuss our theoretical expectations regarding first the relationship between institutional herding presence and mood, based on the above mentioned four mood-proxies. The discussion in section 2.3 showcased how herding can be motivated via both positive and negative mood; to the extent that positive mood reduces risk-aversion and fosters the employment of heuristics in decision-making, fund managers could rely on herding (a heuristic per se) more strongly during periods with positive affective content. However, herding could also manifest itself when mood is negative, as a response towards the greater risk aversion (seeking "safety in numbers") induced by negative mood. ${ }^{22}$ The above suggest that a clear relationship between institutional herding presence and the weekend/holiday/sunshine effects is far from straightforward, since each of those mood-proxies accommodates the potential for both positive (Fridays; pre-holiday day; increased sunshine) and negative (Mondays; postholiday day; decreased sunshine) mood. With respect to Ramadan, the emotional homogeneity it fosters would be expected to enhance the relative homogeneity among fund managers as a group, thus increasing the likelihood of them engaging in stronger herding during Ramadan

\footnotetext{
${ }^{21}$ http://mgm.gov.tr

${ }^{22}$ With negative mood leading individuals to perceive bad outcomes as more likely (Wright and Bower, 1992), it is possible that it can prompt, for example, "bad" fund managers to view their low skills as lower than they actually are, leading them to copy their better peers more intensively.
} 
compared to the rest of the year's months. In view of the above, we propose the following hypotheses:

$\mathrm{H}_{1,0}$ : Herding is expected to be stronger on positive mood days.

$\mathrm{H}_{1,1}$ : Herding is expected to be stronger on negative mood days.

$\mathrm{H}_{2}$ : Herding is expected to be stronger within, than outside, Ramadan.

As regards our expectations on the relationship between mood and institutional herding direction, we would expect to witness stronger buy- (sell-) herding on Fridays, pre holiday days and increased sunshine days (Mondays, post holiday days and decreased sunshine days) which are associated with positive (negative) mood, in view of the fact that positive (negative) mood encourages purchases (sales) of stocks (see e.g. Goetzmann et al., 2015). In the same vein, we would also expect buy- (sell-) herding to be stronger than sell- (buy-) herding on Fridays, pre holiday days and increased sunshine days (Mondays, post holiday days and decreased sunshine days). With respect to Ramadan, given its positive mood content, one would expect institutional herding during that month to be strongly buy-side driven, compared to the rest of the year's months and also buy-herding to be stronger than sell-herding during Ramadan. In view of the above, we propose the following hypotheses:

$\mathrm{H}_{3}$ : Buy-herding is expected to be stronger on positive mood days compared to negative mood days.

$\mathrm{H}_{4}$ : Buy-herding is expected to be stronger than sell-herding on positive mood days.

$\mathrm{H}_{5}$ : Sell-herding is expected to be stronger on negative mood days compared to positive mood ones.

$\mathrm{H}_{6}$ : Sell-herding is expected to be stronger than buy-herding on negative mood days. 
$\mathrm{H}_{7}$ : Buy-herding is expected to be stronger within, than outside, Ramadan.

H8: Buy-herding is expected to be stronger than sell-herding within Ramadan.

\section{Results - Discussion}

\subsection{Unconditional herding results}

We begin the presentation of our results with the estimates from Equation (3) and the concomitant decomposition of $\beta_{\mathrm{t}}$ into its two components (funds following their own trades; funds following the trades of other funds) as per Equation (4) for the full sample period; results are presented in Table 2, Panel A for stocks traded by at least one, two, three or four funds. The employment of those four thresholds is appropriate here in view of the low average daily number (three) of active funds per stock, thus allowing us to assess whether our findings are robust to different levels of institutional equity trading activity. The results outlined in Table 2, Panel A suggest that Turkish funds' equity demand is characterized by significant temporal dependence, as evidenced through the significantly ${ }^{23}$ positive $\beta_{\mathrm{t}}$ values. The latter exhibit a declining trend as the number of active funds per stock increases (from 0.0631 for the $\geq 1$ funds' threshold to 0.0471 for the $\geq 4$ funds' threshold $)^{24}$, thus suggesting that the day-on-day cross correlation of Turkish institutional demand is around 4.7-6.3\%. A closer inspection of $\beta_{\mathrm{t}}$ 's two components reveals interesting patterns; whereas the "funds following their own trades" part is significantly positive (denoting that funds follow their own lagged trades) for the $\geq 1$ funds' threshold, it turns significantly negative (denoting that funds trade against the direction of their own lagged trades) for the rest three thresholds, with that part's value being the most negative

\footnotetext{
${ }^{23}$ Any reference to statistical significance from now on will pertain to estimates with p-values less than 0.1 .

${ }^{24}$ The $\geq 3$ funds' threshold presents us with a marginally lower $\beta_{\mathrm{t}}$ value $(0.0469)$ than the $\geq 4$ funds' threshold; however, both thresholds' $\beta_{\mathrm{t}}$ values are well below those of the $\geq 1$ and $\geq 2$ funds' thresholds.
} 
for the $\geq 4$ funds" threshold. On the other hand, the "funds following the trades of other funds" component is always significantly positive (indicative of significant herding), with its value rising (and from the $\geq 2$ funds' threshold onward, exceeding the $\beta_{\mathrm{t}}$ value) as we move toward the $\geq 4$ funds' threshold. Overall, the evidence suggests the prevalence of herd behaviour among Turkish fund managers, with its magnitude rising as the average daily number of active funds per stock rises.

To assess whether herding varies contingent on its direction (buy; sell), we re-estimate Equation (3) and decompose $\beta_{\mathrm{t}}$ into its two components for predominantly bought $\left(\operatorname{Raw} \Delta_{\mathrm{k}, \mathrm{t}}\right.$ $>0.5)$ and predominantly sold $\left(\operatorname{Raw} \Delta_{\mathrm{k}, \mathrm{t}}<0.5\right)$ stocks, with results presented in Table 2, Panels $\mathrm{B}$ and $\mathrm{C}$, respectively. $\beta_{\mathrm{t}}$ is always significantly positive for sell-herds and significantly positive for the first two thresholds' estimations for buy-herds. Both $\beta_{\mathrm{t}}$ components are mostly significant; the "funds following their own trades" ("funds following the trades of other funds") component is almost always negative (positive), with its values being almost always smaller (larger) for the buy compared to the sell herd and almost always substantially smaller (larger) compared to its corresponding values per threshold in Panel A of Table 2. As a result, funds trade away from their lagged trades more (less) strongly and follow the lagged trades of other funds more (less) when trading stocks that are predominantly bought (sold). With the two $\beta_{\mathrm{t}}$ components strongly countervailing each other, this leads $\beta_{\mathrm{t}}$ to assume lower values in Panels $\mathrm{B}$ and $\mathrm{C}$ compared to Panel A, thus indicating that the temporal dependence of directional (buy; sell) institutional demand is less pronounced compared to that of total institutional demand. The results reported in Panels B and C show that Turkish funds exhibit stronger buy- than sellherding and it is possible that this is due to the asymmetry in complexity involved in a buycompared to a sell-decision: when funds have to choose which stock/s to sell, they have to choose among the given number of stocks in their portfolio; by comparison, the decision to buy a stock is more taxing in terms of time, effort and attention, since it will involve choosing 
among the universe of listed stocks. Herding in this case can function as a useful heuristic, since monitoring the investments of their peers can inform/facilitate the stock selection process for fund managers.

To get a first impression of the interactions of institutional herding with our mood proxies, we pool the latter together in the following multivariate setting:

$\beta_{\mathrm{t}}=\alpha_{0}+\alpha_{1}$ Monday $_{t}+\alpha_{2}$ Holiday $_{t}+\alpha_{3}$ Ramadan $_{t}+\alpha_{4}$ Sunshine $_{t}+\varepsilon_{t}$

In Equation (5), Mondayt is a dummy assuming the value of one on Mondays, zero otherwise; Holidayt is a dummy assuming the value of one pre holiday, zero otherwise; Ramadan $t$ is a dummy assuming the value of one during Ramadan, zero otherwise; and Sunshinet is a dummy assuming the value of one on increased sunshine days, zero otherwise. We also estimate Equation (5) using each of $\beta_{\mathrm{t}}$ 's two components as dependent variable in turn. Results are presented in Table 3 for all four thresholds and, overall, denote the very limited presence of statistically significant estimates (whose significance is always at the $10 \%$ level). These results indicate the absence of any significant relationship between institutional herding and mood and we now turn to testing the interactions of institutional herding with each of the four moodproxies individually in view of the hypotheses proposed in the previous section. ${ }^{25}$

\subsection{Conditional herding results}

Tables 4-7 present the estimates from Equation (3) on the $\beta_{\mathrm{t}}$ and its two components for all four thresholds, when conditioning its estimation on each mood-proxy's states for the full sample of stocks, the buy-herd and the sell-herd. With regards to the full sample of stocks

\footnotetext{
${ }^{25}$ Similar results were discovered when estimating Equation (5) using $\beta_{\mathrm{t}}$ and its two components from the buyand sell-herds. Results are not reported here for brevity reasons and are available from the authors on request.
} 
(Panel $\mathrm{A}$ in Tables 4-7), $\beta_{\mathrm{t}}$ is mostly significantly positive, tending to assume larger values on Mondays, during Ramadan and on decreased sunshine days; on the other hand, it is consistently insignificant on pre/post holiday days (Table 5, Panel A). Regarding buy- and sell-herding (Panels B and C, respectively, in Tables 4-7), results overall indicate a much more limited significance for $\beta_{\mathrm{t}}$, with sell-herding estimates tending to exhibit relatively more significance than buy-herding ones. However, the differences of $\beta_{\mathrm{t}}$ - estimates between different states of each mood-proxy are almost always insignificant, thus denoting that the temporal dependence of institutional demand is independent of mood-states.

The "funds following their own trades" part exhibits similar patterns in Tables 4-7 to its unconditional estimates in Table 2; more specifically, its full-sample, buy-herd and sell-herd estimates tend to be positive for the $\geq 1$ funds' threshold and negative for the rest three thresholds. Although this suggests that the propensity of Turkish fund managers to trade against their previous trades rises with the number of funds active in a stock, no consistent pattern (be it of magnitude or significance) emerges for that component across various mood-states. With very few exceptions (mostly pertaining to some significant Friday-Monday differences in Table 4), the differences in that component's estimates between different mood-states are overwhelmingly insignificant, suggesting that whether Turkish fund managers follow their previous trades or not is not a function of the mood-state prevailing.

We now turn to the "funds following the trades of other funds" part, which is of key interest here, as it reveals the herding tendencies of institutional investors and whether these vary with mood-states. To begin with, both Mondays and Fridays appear to entail significant herding for the full sample (Monday's herding appearing stronger in most cases than Friday's) in Table 4, Panel A, while Fridays tend to accommodate consistently significant sell-herding (Table 4, Panel C); sell-herding on Mondays is less significant, while neither day exhibits widespread evidence of buy-herding (Table 4, Panel B). The buy- (sell-) herding of Mondays (Fridays) 
appears to be significantly stronger compared to that of Fridays' (Mondays') for the $\geq 3$ and 4 (2 and 3) funds' thresholds, as the significant p-values of the relevant tests of difference suggest. When only the thresholds with jointly significant buy- and sell-herding estimates are considered (i.e. the $\geq 3$ and 4 funds' thresholds), we notice that buy- (sell-) herding is stronger than sell- (buy-) herding for Mondays (Fridays). As regards holidays, the "funds following the trades of other funds" part is significant on pre-holiday days only for some tests, without, however, its difference from its equivalent post-holidays days' estimates being significant (Table 5).

With respect to Ramadan, Turkish funds tend to herd more strongly within, compared to outside, that month, without the difference of those estimates within-versus-outside Ramadan being significant on any occasion (Table 6, panel A). There exists some very strong buyherding within-Ramadan for the $\geq 3$ and 4 funds' thresholds (Table 6, Panel B) which is larger in value than the outside-Ramadan buy-herding; although this is in line with theoretical expectations on the month's positive mood prompting equity purchases, the difference of buyherding within-versus-outside Ramadan is insignificant for both thresholds. Non-Ramadan days are characterized by consistently significant sell-herding, while no evidence of the latter is reported for Ramadan, whatsoever; despite that, non-Ramadan sell-herding is found to be significantly different from Ramadan's for the $\geq 1$ funds' threshold only (Table 6 , Panel C). Interestingly enough, non-Ramadan sell-herding is smaller in magnitude than non-Ramadan's buy-herding; taken together with the strong buy-herding reported in-Ramadan for the $\geq 3$ and 4 funds' thresholds (and the absence of sell-herding during Ramadan; Table 6, Panel B), it indirectly confirms that Turkish fund managers herd more strongly on the buy- than the sellside (in line with the unconditional herding results from Table 2). ${ }^{26}$

\footnotetext{
${ }^{26}$ Białkowski et al. (2013) argued that market returns in majority Muslim countries tend to rise after the three-and-a-half day celebration (known as Ramazan Bayrami in Turkey, a public holiday for which we have already accounted in our holiday
} 
Decreased sunshine days tend to entail stronger herding (Table 7, Panel A), while buy-herding is stronger during increased sunshine days (Table 7, Panel B); the latter is in line with theoretical expectations, according to which fund managers would be expected to buy-herd more on days of positive mood. Evidence on sell-herding is rather mixed, as decreased sunshine days have stronger sell-herding for two thresholds ( $\geq 2$ and 3 funds' thresholds), while sellherding is present for the $\geq 4$ funds' threshold for increased sunshine days only (Table 7 , Panel C). Again here, the differences between increased and decreased sunshine herding estimates are insignificant in all cases. Buy-herding tends to be stronger than sell-herding for increased sunshine days (see the $\geq 2,3$ and 4 funds' thresholds), while decreased sunshine days demonstrate no clear buy-versus-sell herding pattern in that respect.

Overall, the results outlined in Tables 4-7 suggest that institutional herding in Turkey enjoys no robust relationship with mood when accounting for various mood proxies. Although some herding patterns in line with expectations do occasionally arise (e.g. stronger buy-herding on increased sunshine days and during Ramadan), these are neither confirmed for all thresholds of funds' equity trading activity tested for, nor are their differences with their complementary mood state's herding (e.g. decreased sunshine days and non-Ramadan days) significant. As a result, our evidence supports none of the hypotheses we proposed in section 3.2 on the relationship of mood with both institutional herding presence and direction.

A possible explanation for the absence of such a relationship is that fund managers are sophisticated investors, whose trading conduct is not subject to mood-effects; however plausible this may appear, it need not always hold, given the evidence from Goetzmann et al. (2015) on weather-effects on US institutional trades. Alternatively, the lack of a mood-herding

effect tests) following the Ramadan's completion and proposed an alternative identification of the Ramadan-period with one including not only the Ramadan-month in itself, but also the seven days following the Ramazan Bayrami. We explored whether our results vary when using their definition of Ramadan, yet again found no significant difference in institutional herding inversus-outside Ramadan. Results are not presented here in the interest of brevity and are available upon request. 
relationship may be due to mood-effects varying among investment professionals on the premises of their experience. It is possible, for instance, that more (less) experienced fund managers are less (more) subject to mood-effects, in line with the findings of Lo and Repin (2002) on longer-tenure derivatives' traders exhibiting a reduced emotional footprint to market volatility compared to their shorter-tenure peers. If true, such effects would be expected to dissipate when averaged out across all fund managers - which is the case with this study (given the lack of data on Turkish managers' experience-levels).

\subsection{Robustness tests}

The evidence presented so far suggests that mood does not affect the propensity of Turkish fund managers to herd, with their herding found to be insignificantly different across various mood states in almost all cases. As a first robustness test of our findings, we first remove the 14 index funds of our data set from our sample and repeat all estimations from Tables 4-7. The reason for removing all index funds pertains to the fact that these funds are trackers in nature that rebalance their portfolios mechanically, aiming at replicating the composition and performance of the index they are benchmarked against. Including these funds in our estimations raises the possibility of our results being affected by the trades of funds motivated by passive investing and which, as a result, would not be expected to be related to mood per se. The estimates we obtain following the removal of those 14 funds from the sample are qualitatively similar to those reported in Tables 4-7 and confirm the absence of any moodeffects over Turkish fund managers' herding. ${ }^{27}$

\footnotetext{
${ }^{27}$ Results are not reported here for reasons of brevity and are available from the authors on request.
} 
We then explore whether our results are driven by the size effect, a well-known determinant of institutional herding internationally (Andrikopoulos et al., 2017). To that end, we rank the universe of stocks that our sample funds have invested in each year into five quintiles (Q1 to Q5, with Q1 corresponding to the smallest and Q5 to the largest capitalization stocks) based on those stocks' market capitalization ${ }^{28}$ at the end of the immediately preceding year and repeat all estimations from Tables 4-7. Results ${ }^{29}$ confirm, by and large, the original full-sample results on institutional herding being insignificantly different across various mood states, thus indicating the absence of any size effect in our estimates. Moreover, the "funds following the trades of other funds" consistently assumes its lowest value for quintile 1, suggesting that Turkish fund managers herd the least in stocks of the smallest capitalization, irrespective of the mood state tested. A possible reason for this is that the relatively lower volumes typifying small stocks reduce the feasibility of herding by leading to delays in order-execution, thus rendering it more difficult for investors wishing to herd (indeed, to engage in any trading strategy) to do so uninhibitedly (Andrikopoulos et al., 2017).

\section{Conclusion}

In this paper we empirically assess the relationship between mood and institutional investors' herding for the first time in the literature. Drawing on the daily portfolio holdings of Turkish funds, we study this relationship on the premises of a series of established mood proxies, including the weekend effect, the holiday effect, Ramadan and sunshine. Overall, fund managers in Turkey herd significantly, with their herding growing in magnitude as the number of active funds per stock rises and appearing stronger on the buy- than the sell-side. Regarding

\footnotetext{
${ }^{28}$ Data on our sample stocks' market capitalization was obtained from the Thomson Reuters Data Stream database.

${ }^{29}$ Results are not reported here for brevity reasons and are available from the authors on request.
} 
the relationship of mood with institutional herding, it occasionally assumes the correct sign as per theoretical expectations; however, institutional herding is found to be insignificantly different across various mood states, thus showcasing that the propensity of fund managers to herd is not subject to the impact of mood. These results further indicate that the pursuit of a behavioural trading pattern by institutional investors does not necessarily render them moodprone in their trading conduct (more so given their sophisticated nature) and contribute to the debate on the role of less-than-perfectly rational factors over investors' herding, in general.

The evidence presented in our paper is of particular interest to researchers, since the lack of a significant effect of mood over institutional herding documented here raises the question of whether this holds internationally across markets with differences in their size, financial development, institutional design and asset management industry structure. Given the mixed extant evidence (Goetzmann et al., 2015; Kaustia and Rantapuska, 2016) on the role of weather-related mood proxies over institutional trading behaviour, it is not unlikely that the effect of mood over institutional herding may vary internationally. An issue arising is whether mood-factors commonly affecting some markets (such as Ramadan in majority Muslim markets) produce similar effects over these markets' institutional herding. Our findings are also of interest to practitioners keen on exploiting potential market inefficiencies, since a significant relationship of institutional herding in a market with a mood-factor could be used to inform their trading strategies. If, for example, institutional herding interacts significantly with a weather-variable (e.g. rain or temperature) an investor can rely on rain/temperature forecasts to trade in/against the anticipated direction of institutional herding while also employing weather derivatives to hedge their positions. 


\section{References}

Andrikopoulos, P., Kallinterakis, V., Leite Ferreira, M.P. and Verousis, T. (2017). Intraday herding on a cross-border exchange. International Review of Financial Analysis, 53, 25-36. Ardalan, K. (2018). Neurofinance versus the efficient markets hypothesis. Global Finance Journal, 35, 170-176

Au, K., Chan, F., Wang, D., Vertinsky, I. (2003). Mood in foreign exchange trading: Cognitive processes and performance. Organizational Behavior and Human Decision Processes, 91, 322338.

Baker, M., and Wurgler, J. (2007). Investor sentiment in the stock market. Journal of Economic Perspectives, 21, 129-151.

Banerjee, A.V. (1992). A simple model of herd behavior. Quarterly Journal of Economics 107, 797-817.

Bassi, A., Colacito, R. and Fulghieri, P. (2013). O sole mio: an experimental analysis of weather and risk attitudes in financial decisions. Review of Financial Studies, 26 (7), 18241852.

Beckmann, D., Menkhoff, L. and Suto, M. (2008). Does culture influence asset managers' views and behavior? Journal of Economic Behavior and Organization, 67 (3-4), 624-643.

Białkowski, J., Bohl, M.T., Kaufmann, P. and Wisnievski, T.P. (2013). Do mutual fund managers exploit the Ramadan anomaly? Evidence from Turkey. Emerging Markets Review, $15,211-232$.

Białkowski, J., Etebari, A. and Wisniewski, T.P. (2012). Fast profits: investor sentiment and stock returns during Ramadan. Journal of Banking and Finance, 36(3), 835-845.

Bikhchandani, S., Hirshleifer, D. and Welch, I. (1992). A theory of fads, fashion, custom, and cultural change as informational cascades. Journal of Political Economy 100, 992-1026. 
Birru, J. (2016). Day of the week and the cross-section of returns. Ohio State University, Fisher College of Business Working Paper No. 2016-03-01.

Blake, D., Sarno, L. and Zinna, G. (2017). The market for lemmings: the herding behavior of pension funds. Journal of Financial Markets, 26, 17-39.

Brounen, D. and Derwall, J. (2010). The impact of terrorist attacks on international stock markets. European Financial Management, 16(4), 585-598.

Brunnermeier, M.K. and Nagel, S. (2004). Hedge funds and the technology bubble. Journal of Finance, 59(5), 2013-2040.

Cao, M., and Wei, J. (2005). Stock market returns: A note on temperature anomaly. Journal of Banking and Finance, 29, 1559-1573.

Celiker, U., Chowdhury, J. and Sonaer, G. (2015). Do mutual funds herd in industries? Journal of Banking and Finance, 52, 1-16.

Chang, C-H and Lin, S-J (2015). The effects of national culture and behavioral pitfalls on investors' decision-making: herding behavior in international stock markets. International Review of Economics and Finance, 37, 380-392.

Choi, N. and Sias, R.W. (2009). Institutional industry herding. Journal of Financial Economics, 94, 469-491.

Choi, N., and Skiba, H. (2015). Institutional herding in international markets. Journal of Banking and Finance, 55, 246-259.

De Bondt, W.F.M. and Teh, L.L. (1997). Herding behavior and stock returns: An exploratory investigation. Swiss Journal of Economics and Statistics 133, 293-324.

Economou, F., Gavriilidis, K., Kallinterakis, V. and Yordanov, N. (2015). Do fund managers herd in frontier markets-and why? International Review of Financial Analysis, 40, 76-87.

Edmans, A., Garcia, D. and Norly, Ø. (2007). Sports sentiment and stock returns. Journal of Finance, 62(4), 1967-1998. 
Eun, C.S., Wang, L. and Xiao, S.C. (2015). Culture and R². Journal of Financial Economics, $115,283-303$.

Fabozzi, F.J., Ma, C.K. and Briley, J.E. (1994). Holiday trading in futures markets. Journal of Finance, 49 (1), 307-324.

Forgas, J.P. (1995). Mood and judgment: the affect infusion model (AIM). Psychological Bulletin, 117 (1), 39-66.

Forgas, J.P. (1998). On being happy and mistaken: mood effects on the fundamental attribution error. Journal of Personality and Social Psychology, 75 (2), 318-331.

Frijda, N.H. (1993). Moods, emotion episodes, and emotions. In: Haviland, J.M., Lewis, M. (editors). Handbook of emotions. New York: The Guilford Press. 381-403.

Gavriilidis, K., Kallinterakis, V. and Leite-Ferreira, M.P. (2013). Institutional industry herding: Intentional or spurious? Journal of International Financial Markets, Institutions and Money 26, 192-214.

Gavriilidis, K., Kallinterakis, V. and Tsalavoutas, I. (2016). Investor mood, herding and the Ramadan effect. Journal of Economic Behavior and Organization, 132, 23-38.

Gelos, R.G. and Wei, S.-J. (2005). Transparency and international portfolio holdings. Journal of Finance, 60, 2987-3020.

Goetzmann, W.N., Kim, D., Kumar, A. and Wang, Q. (2015). Weather-induced mood, institutional investors, and stock returns. Review of Financial Studies, 28, 73-111.

Goetzmann, W.N. and Zhu, N. (2005). Rain or shine: where is the weather effect? European Financial Management, 11 (5), 559-578.

Griffin, J. M., Harris, J. H., Shu, T. and Topaloglou, S. (2011). Who drove and burst the tech bubble? Journal of Finance, 66 (4), 1251-1290. 
Guney, Y., Kallinterakis, V. and Komba, G. (2017). Herding in frontier markets: Evidence from African stock exchanges. Journal of International Financial Markets, Institutions and Money, 47, 152-175.

Hirshleifer, D. and Shumway, T. (2003). Good day sunshine: stock returns and the weather. Journal of Finance, 58, 1009-1032.

Hirshleifer, D. and Teoh, S.T. (2003). Herd behavior and cascading in capital markets: A review and synthesis. European Financial Management 9, 25-66.

Holmes, P.R., Kallinterakis, V. and Leite-Ferreira, M.P. (2013). Herding in a concentrated market: A question of intent. European Financial Management, 19, 497-520.

Isen, A. M. (2000). Positive affect and decision making. In Lewis, M. and Haviland-Jones, J. (Eds.), Handbook of Emotions (2nd ed., pp. 417-435). New York: Guilford.

Jiao, Y. and Ye, P. (2014). Mutual fund herding in response to hedge fund herding and the impacts on stock prices. Journal of Banking and Finance, 49, 131-148.

Jin, L. and Scherbina, A. (2011). Inheriting losers. Review of Financial Studies, 24 (3), 786820.

Kamstra, J, Kramer, L.A. and Levi, M.D. (2003). Winter blues: a SAD stock market cycle. American Economic Review, 93 (1), 324-343.

Kaplanski, G. and Levy, H. (2010). Sentiment and stock prices: The case of aviation disasters. Journal of Financial Economics, 95(2), 174-201.

Kaustia, M. and Rantapuska, E. (2016). Does mood affect trading behavior? Journal of Financial Markets, 29, 1-26.

Kuhnen, C.M. and Knutson, B. (2011). The influence of affect on beliefs, preferences and financial decisions. Journal of Financial and Quantitative Analysis, 46 (3), 605-626. 
Lahav, E., Shavit, T. and Benzion, U. (2016). Can't wait to celebrate: holiday euphoria, impulsive behavior and time preference. Journal of Behavioral and Experimental Economics, $65,128-134$

Lakonishok, J., Schleifer, A. and Vishny, R.W. (1992). The impact of institutional trading on stock prices. Journal of Financial Economics, 32(1). 23-43.

Lakonishok, J. and Smidt, S. (1988). Are seasonal anomalies real? A ninety-year perspective. Review of Financial Studies, 1 (4), 403-425.

Liao, T.-L., C.-J. Huang and Wu, C.-W. (2011), Do Fund Managers Herd to Counter Investor Sentiment?, Journal of Business Research, 64, 207-212.

Lo, A.W. and Repin, D. V. (2002). The psychophysiology of real-time financial risk processing. Journal of Cognitive Neuroscience, 3, 323-339.

Lucey, B.M. and Dowling, M. (2005). The role of feelings in investor decision-making. Journal of Economic Surveys, 19(2), 211-237.

Meneu, V. and Pardo, A. (2004). Pre-holiday effect, large trades and small investor behavior. Journal of Empirical Finance, 11, 231-246.

Mittal, V., and Ross, W.T.J. (1998). The impact of positive and negative affect and issue framing on issue interpretation and risk taking. Organizational Behavior and Human Decision Processes, 76, 298-324.

Morse, J.N., Nguyen, H. and Quach, H.M. (2014). Day-of-the-week trading patterns of individual and institutional investors. Global Business and Finance Review, 19 (2), 53-60.

Olson, K.R. (2006). A literature review of social mood. Journal of Behavioral Finance, 7 (4), 193-203.

Pérez-González, F. and Yun, H. (2013). Risk management and firm value: evidence from weather derivatives. Journal of Finance, 68 (5), 2143-2176. 
Saunders, E.M.J. (1993). Stock prices and Wall Street weather. American Economic Review, $83,1337-1345$.

Scharfstein, D.S., Stein, J.C. (1990). Herd behavior and investment. American Economic Review 80, 465-479.

Schmittmann, J.M., Pirschel, J., Meyer, S. and Hackethal, A. (2015). The impact of weather on German retail investors. Review of Finance, 19 (3), 1143-1183.

Schwarz, N. (2002). Feelings as information: Moods influence judgments and processing strategies. In: Gilovich, T., Griffin, D. and Kahneman, D. (editors). Heuristics and biases: The psychology of intuitive judgment. New York: Cambridge University Press, 534-547.

Sias, R.W. (2004). Institutional herding. Review of Financial Studies, 17, 165-206.

Singh, V. (2013). Did institutions herd during the internet bubble? Review of Quantitative Finance and Accounting, 41 (3), 513-534.

Spyrou, S. (2013). Herding in financial markets: a review of the literature. Review of Behavioral Finance 5, 175-194.

Stambaugh, R.F. (2014). Presidential Address: Investment noise and trends. Journal of Finance, 69 (4), 1415-1453.

Taffler, R. (2018). Emotional finance: investment and the unconscious. European Journal of Finance, 24(7-8), 630-653.

Voronkova, S. and Bohl, M.T. (2005). Institutional traders' behavior in an emerging stock market: Empirical evidence on Polish pension fund investors. Journal of Business, Finance and Accounting, 32, 1537-1560.

Wermers, R. (1999). Mutual fund herding and the impact on stock prices. Journal of Finance $54,581-622$.

Wright, W.F. and Bower, G.H. (1992). Mood effects on subjective probability assessment. Organizational Behavior and Human Decision Processes, 52, 276-291. 
Table 1: Descriptive statistics

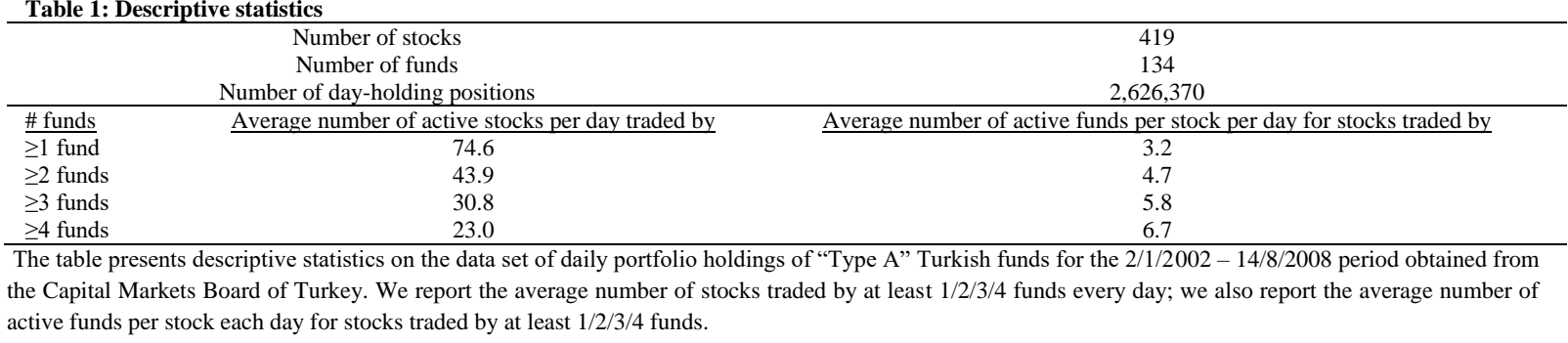

Table 2: Tests for herding presence- Buyer if increased position

\begin{tabular}{|c|c|c|c|}
\hline \multirow[b]{2}{*}{ Average coefficient $\left(\beta_{t}\right)$} & \multicolumn{2}{|c|}{$\begin{array}{l}\text { Partitioned slope coefficient } \\
\end{array}$} & \multirow[b]{2}{*}{ Average $\mathrm{R}^{2}$} \\
\hline & $\begin{array}{l}\text { Funds following } \\
\text { their own trades }\end{array}$ & $\begin{array}{l}\text { Funds following the trades of } \\
\text { other funds }\end{array}$ & \\
\hline \multicolumn{4}{|l|}{ Panel A: Unconditional herding } \\
\hline \multicolumn{4}{|l|}{ No of active funds per stock $\geq 1$} \\
\hline $\begin{array}{c}0.0631 \\
(0.0000)\end{array}$ & $\begin{array}{c}0.0090 \\
(0.0501)\end{array}$ & $\begin{array}{c}0.0541 \\
(0.0000)\end{array}$ & 0.0294 \\
\hline \multicolumn{4}{|l|}{ No of active funds per stock $\geq 2$} \\
\hline $\begin{array}{r}0.0596 \\
(0.0000)\end{array}$ & $\begin{array}{l}-0.0325 \\
(0.0000)\end{array}$ & $\begin{array}{c}0.0920 \\
(0.0000)\end{array}$ & 0.0407 \\
\hline \multicolumn{4}{|l|}{ No of active funds per stock $\geq 3$} \\
\hline $\begin{array}{c}0.0469 \\
(0.0000)\end{array}$ & $\begin{array}{l}-0.0582 \\
(0.0000)\end{array}$ & $\begin{array}{c}0.1051 \\
(0.0000)\end{array}$ & 0.0535 \\
\hline \multicolumn{4}{|l|}{ No of active funds per stock $\geq 4$} \\
\hline $\begin{array}{c}0.0471 \\
(0.0000) \\
\end{array}$ & $\begin{array}{l}-0.0629 \\
(0.0000) \\
\end{array}$ & $\begin{array}{r}0.1100 \\
(0.0000)\end{array}$ & 0.0674 \\
\hline \multicolumn{4}{|c|}{ Panel B: Tests for herding direction- buy herding } \\
\hline \multicolumn{4}{|c|}{ No of active funds per stock $\geq 1$} \\
\hline $\begin{array}{c}0.0318 \\
(0.0000)\end{array}$ & $\begin{array}{c}0.0341 \\
(0.0082)\end{array}$ & $\begin{array}{l}-0.0023 \\
(0.8640)\end{array}$ & 0.0520 \\
\hline \multicolumn{4}{|l|}{ No of active funds per stock $\geq 2$} \\
\hline $\begin{array}{cc}0.0222 \\
(0.0042)\end{array}$ & $\begin{array}{l}-0.1777 \\
(0.0005)\end{array}$ & $\begin{array}{c}0.1999 \\
(0.0001)\end{array}$ & 0.0950 \\
\hline \multicolumn{4}{|l|}{ No of active funds per stock $\geq 3$} \\
\hline $\begin{array}{r}0.0137 \\
(0.1249)\end{array}$ & $\begin{array}{l}-0.2519 \\
(0.0000)\end{array}$ & $\begin{array}{c}0.2656 \\
(0.0000)\end{array}$ & 0.1174 \\
\hline \multicolumn{4}{|l|}{ No of active funds per stock $\geq 4$} \\
\hline $\begin{array}{r}0.0053 \\
(0.7435) \\
\end{array}$ & $\begin{array}{l}-0.4075 \\
(0.0000) \\
\end{array}$ & $\begin{array}{c}0.4128 \\
(0.0000)\end{array}$ & 0.1627 \\
\hline \multicolumn{4}{|c|}{ Panel C: Tests for herding direction-sell herding } \\
\hline \multicolumn{4}{|l|}{ No of active funds per stock $\geq 1$} \\
\hline $\begin{array}{c}0.0492 \\
(0.0000)\end{array}$ & $\begin{array}{c}0.0207 \\
(0.1208)\end{array}$ & $\begin{array}{c}0.0285 \\
(0.0421)\end{array}$ & 0.0523 \\
\hline \multicolumn{4}{|l|}{ No of active funds per stock $\geq 2$} \\
\hline $\begin{array}{c}0.0318 \\
(0.0000)\end{array}$ & $\begin{array}{l}-0.1333 \\
(0.0003)\end{array}$ & $\begin{array}{c}0.1651 \\
(0.0000)\end{array}$ & 0.0942 \\
\hline \multicolumn{4}{|l|}{ No of active funds per stock $\geq 3$} \\
\hline $\begin{array}{c}0.0231 \\
(0.0077)\end{array}$ & $\begin{array}{l}-0.1468 \\
(0.0000)\end{array}$ & $\begin{array}{c}0.1699 \\
(0.0000)\end{array}$ & 0.1159 \\
\hline \multicolumn{4}{|l|}{ No of active funds per stock $\geq 4$} \\
\hline $\begin{array}{r}0.0312 \\
(0.0023) \\
\end{array}$ & $\begin{array}{l}-0.0650 \\
(0.6914)\end{array}$ & $\begin{array}{c}0.0962 \\
(0.5572)\end{array}$ & 0.1419 \\
\hline
\end{tabular}

This table reports the estimates from the equation: $\Delta_{\mathrm{k}, \mathrm{t}}=\beta_{\mathrm{t}} \Delta_{\mathrm{k}, \mathrm{t}-1}+\varepsilon_{\mathrm{k}, \mathrm{t}}$ for the full sample of stocks (Panel A), for stocks predominantly bought (i.e. for stocks whose $R a w \Delta_{\mathrm{k}, \mathrm{t}}>0.5$; Panel B) and for stocks predominantly sold (i.e. for stocks whose $R a w \Delta_{\mathrm{k}, \mathrm{t}}<0.5$; Panel C). For each security and day between 02/01/2002 and 14/08/2008 we calculate the fraction of funds that increase their position in the security. A fund is defined as increasing its position if it holds a greater fraction of the firm's shares at the end of day $t$ than it held at the end of day $t$ - 1 . All data are standardized (i.e. rescaled to zero mean, unit variance) each day. We then estimate daily cross sectional regressions of institutional demand on lagged institutional demand for the full sample of stocks (Panel A), stocks predominantly bought (Panel B) and stocks predominantly sold (Panel C). Because $\Delta_{\mathrm{k}, \mathrm{t}-1}$ is the sole independent variable in each regression and the data are standardized, these regression coefficients are also the cross sectional correlations between institutional demand and lagged institutional demand. Parentheses include p-values. 
Table 3: Multivariate regression on the effect of mood proxies over institutional herding

\begin{tabular}{|c|c|c|c|}
\hline & Dependent variable: $\beta_{t}$ & $\begin{array}{l}\text { Dependent variable: } \\
\text { "Funds following their own trades" }\end{array}$ & $\begin{array}{l}\text { Dependent variable: } \\
\text { "Funds following the trades of other funds" }\end{array}$ \\
\hline \multicolumn{4}{|c|}{ Panel A: No of active funds per stock $\geq 1$} \\
\hline \multirow[t]{2}{*}{ Constant } & 0.0606 & 0.0051 & 0.0555 \\
\hline & $(0.0000)$ & $(0.4344)$ & $(0.0000)$ \\
\hline \multirow[t]{2}{*}{ Monday $_{t}$} & -0.0051 & -0.0011 & -0.0040 \\
\hline & $(0.6047)$ & $(0.9238)$ & $(0.6716)$ \\
\hline \multirow[t]{2}{*}{ Holiday $_{t}$} & -0.0457 & -0.0124 & -0.0332 \\
\hline & $(0.1083)$ & $(0.7043)$ & $(0.2238)$ \\
\hline \multirow{2}{*}{ Ramadan $_{t}$} & 0.0176 & 0.0290 & -0.0114 \\
\hline & $(0.2515)$ & $(0.1007)$ & $(0.4406)$ \\
\hline \multirow[t]{2}{*}{ Sunshine $_{t}$} & 0.0090 & 0.0070 & 0.0020 \\
\hline & $(0.2681)$ & $(0.4532)$ & $(0.7990)$ \\
\hline $\mathrm{R}^{2}$ & 0.0031 & 0.0020 & 0.0015 \\
\hline \multicolumn{4}{|c|}{ Panel B: No of active funds per stock $\geq 2$} \\
\hline \multirow[t]{2}{*}{ Constant } & 0.0563 & -0.0290 & 0.0853 \\
\hline & $(0.0000)$ & $(0.0000)$ & $(0.0000)$ \\
\hline \multirow[t]{2}{*}{ Monday $_{t}$} & 0.0132 & -0.0004 & 0.0136 \\
\hline & $(0.2749)$ & $(0.9741)$ & $(0.3191)$ \\
\hline \multirow[t]{2}{*}{ Holiday $_{t}$} & -0.0297 & -0.0372 & 0.0075 \\
\hline & $(0.3922)$ & $(0.2408)$ & $(0.8482)$ \\
\hline \multirow[t]{2}{*}{$\operatorname{Ramadan}_{\mathrm{t}}$} & 0.0282 & 0.0141 & 0.0140 \\
\hline & $(0.1331)$ & $(0.4087)$ & $(0.5063)$ \\
\hline \multirow[t]{2}{*}{ Sunshine $_{t}$} & -0.0029 & -0.0089 & 0.0060 \\
\hline & $(0.7714)$ & $(0.3274)$ & $(0.5917)$ \\
\hline $\mathrm{R}^{2}$ & 0.0025 & 0.0018 & 0.0010 \\
\hline \multicolumn{4}{|c|}{ Panel C: No of active funds per stock $\geq 3$} \\
\hline \multirow[t]{2}{*}{ Constant } & 0.0468 & -0.0542 & 0.1010 \\
\hline & $(0.0000)$ & $(0.0000)$ & $(0.0000)$ \\
\hline \multirow[t]{2}{*}{ Monday $_{t}$} & -0.0103 & -0.0253 & 0.0151 \\
\hline & $(0.4719)$ & $(0.0914)$ & $(0.4051)$ \\
\hline \multirow[t]{2}{*}{ Holidayt } & -0.0515 & -0.0558 & 0.0043 \\
\hline & $(0.2093)$ & $(0.1955)$ & $(0.9336)$ \\
\hline \multirow[t]{2}{*}{ Ramadan $_{t}$} & 0.0227 & 0.0104 & 0.0122 \\
\hline & $(0.3050)$ & $(0.6434)$ & $(0.6625)$ \\
\hline \multirow[t]{2}{*}{ Sunshine $_{t}$} & 0.0038 & 0.0037 & 0.0001 \\
\hline & $(0.7441)$ & $(0.7646)$ & $(0.9928)$ \\
\hline $\mathrm{R}^{2}$ & 0.0019 & 0.0029 & 0.0005 \\
\hline \multicolumn{4}{|c|}{ Panel D: No of active funds per stock $\geq 4$} \\
\hline \multirow[t]{2}{*}{ Constant } & 0.0402 & -0.0639 & 0.1040 \\
\hline & $(0.0000)$ & $(0.0000)$ & $(0.0000)$ \\
\hline \multirow[t]{2}{*}{ Monday $_{t}$} & 0.0223 & 0.0030 & 0.0193 \\
\hline & $(0.1797)$ & $(0.8187)$ & $(0.3131)$ \\
\hline \multirow[t]{2}{*}{ Holiday $_{t}$} & -0.0825 & -0.0517 & -0.0309 \\
\hline & $(0.0830)$ & $(0.1732)$ & $(0.5724)$ \\
\hline \multirow[t]{2}{*}{ Ramadan $_{t}$} & 0.0441 & 0.0090 & 0.0351 \\
\hline & $(0.0860)$ & $(0.6584)$ & $(0.2350)$ \\
\hline Sunshine $_{\mathrm{t}}$ & 0.0027 & 0.0024 & 0.0003 \\
\hline & $(0.8447)$ & $(0.8287)$ & $(0.9837)$ \\
\hline $\mathrm{R}^{2}$ & 0.0045 & 0.0013 & 0.0016 \\
\hline
\end{tabular}

The table presents the estimates from the following multivariate regression: $\beta_{\mathrm{t}}=\alpha_{0}+\alpha_{1}$ Monday $_{t}+\alpha_{2}$ Holiday $_{t}+\alpha_{3}$ Ramadan $_{t}+\alpha_{4}$ Sunshine $_{t}$ $+\varepsilon_{t}$. Monday $y_{t}$ is a dummy assuming the value of one on Mondays, zero otherwise; Holiday $y_{t}$ is a dummy assuming the value of one pre holiday, zero otherwise; Ramadan $_{t}$ is a dummy assuming the value of one during Ramadan, zero otherwise; and Sunshine ${ }_{t}$ is a dummy assuming the value of one on increasing sunshine days, zero otherwise. The regressand in each of the three regressions is $\beta_{t}$, "Funds following their own trades" and "Funds following the trades of other funds", respectively. Parentheses include p-values. 
Table 4: Tests for herding presence-herding and the weekend effect

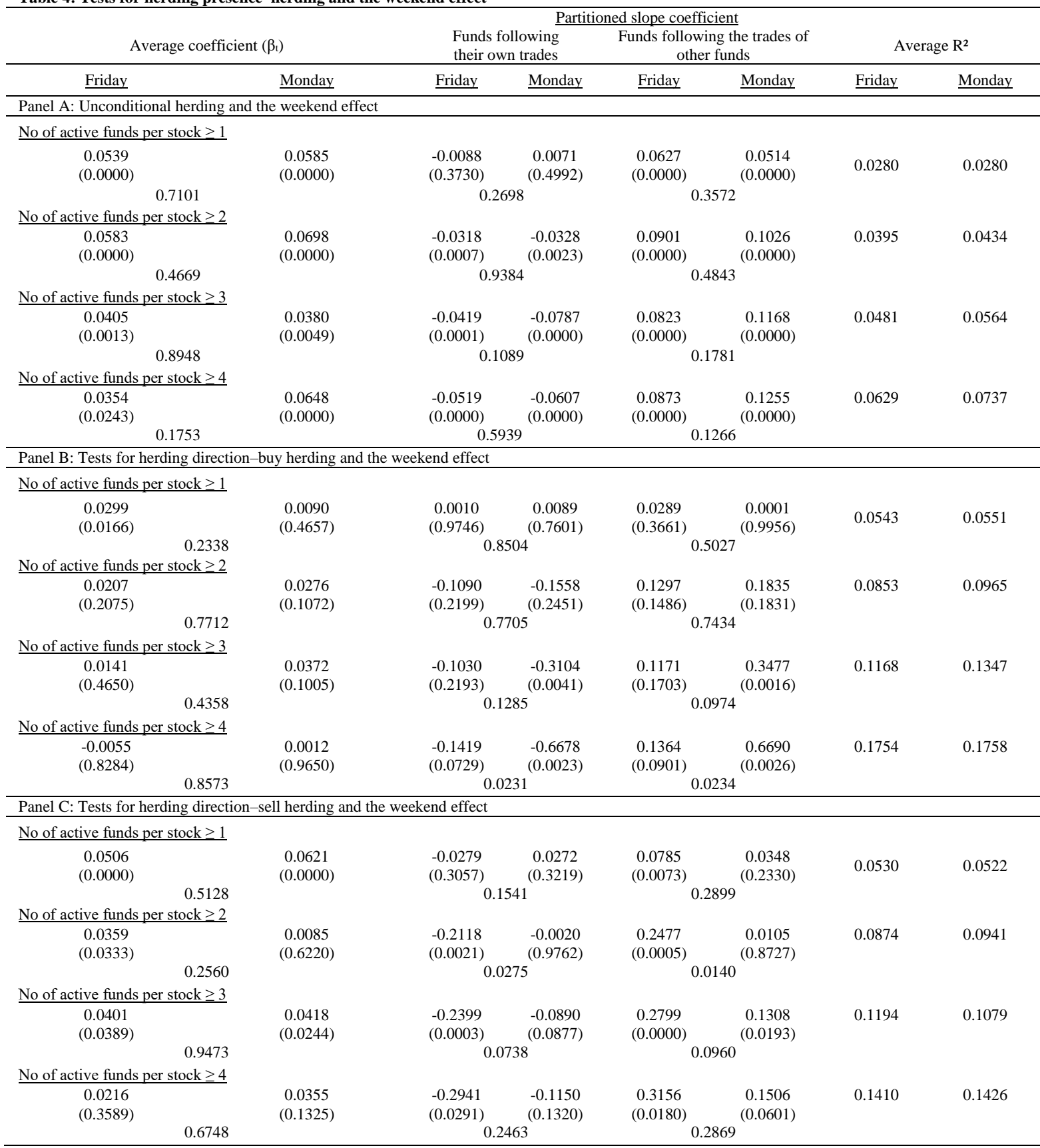

This table reports the estimates from the equation: $\Delta_{\mathrm{k}, \mathrm{t}}=\beta_{\mathrm{t}} \Delta_{\mathrm{k}, \mathrm{t}-1}+\varepsilon_{\mathrm{k}, \mathrm{t}}$ for Mondays and Fridays for the full sample of stocks (Panel A), for stocks predominantly bought (i.e. for stocks whose $R a w \Delta_{\mathrm{k}, \mathrm{t}}>0.5$; Panel B) and for stocks predominantly sold (i.e. for stocks whose $R a w \Delta_{\mathrm{k}, \mathrm{t}}$ $<0.5$; Panel C). For each security and day between January, $2^{\text {nd }} 2002$ and August $14^{\text {th }}, 2008$ we calculate the fraction of funds that increase their position in the security. A fund is defined as increasing its position if it holds a greater fraction of the firm's shares at the end of day $t$ than it held at the end of day $t$ - 1 . All data are standardized (i.e. rescaled to zero mean, unit variance) each day for Mondays and Fridays. We then estimate daily cross sectional regressions of institutional demand on lagged institutional demand once for Mondays and once for Fridays only for the full sample of stocks (Panel A), stocks predominantly bought (Panel B) and stocks predominantly sold (Panel C). Because $\Delta_{\mathrm{k}, \mathrm{t}-1}$ is the sole independent variable in each regression and the data are standardized, these regression coefficients are also the cross sectional correlations between institutional demand and lagged institutional demand for that sample on Mondays and Fridays, respectively. The first column reports the time-series' average of these correlation coefficients and associated p-values (in parentheses) for each of the two days. The second and third columns report the portion of the correlation resulting from funds following their own lagged trades and the portion resulting from funds following the previous trades of other funds (herding) for each of the two days. P-values of Wald test-statistics of difference between Friday-Monday estimates are included underneath each pair of estimates. 
Table 5: Tests for herding presence-herding and the holiday effect

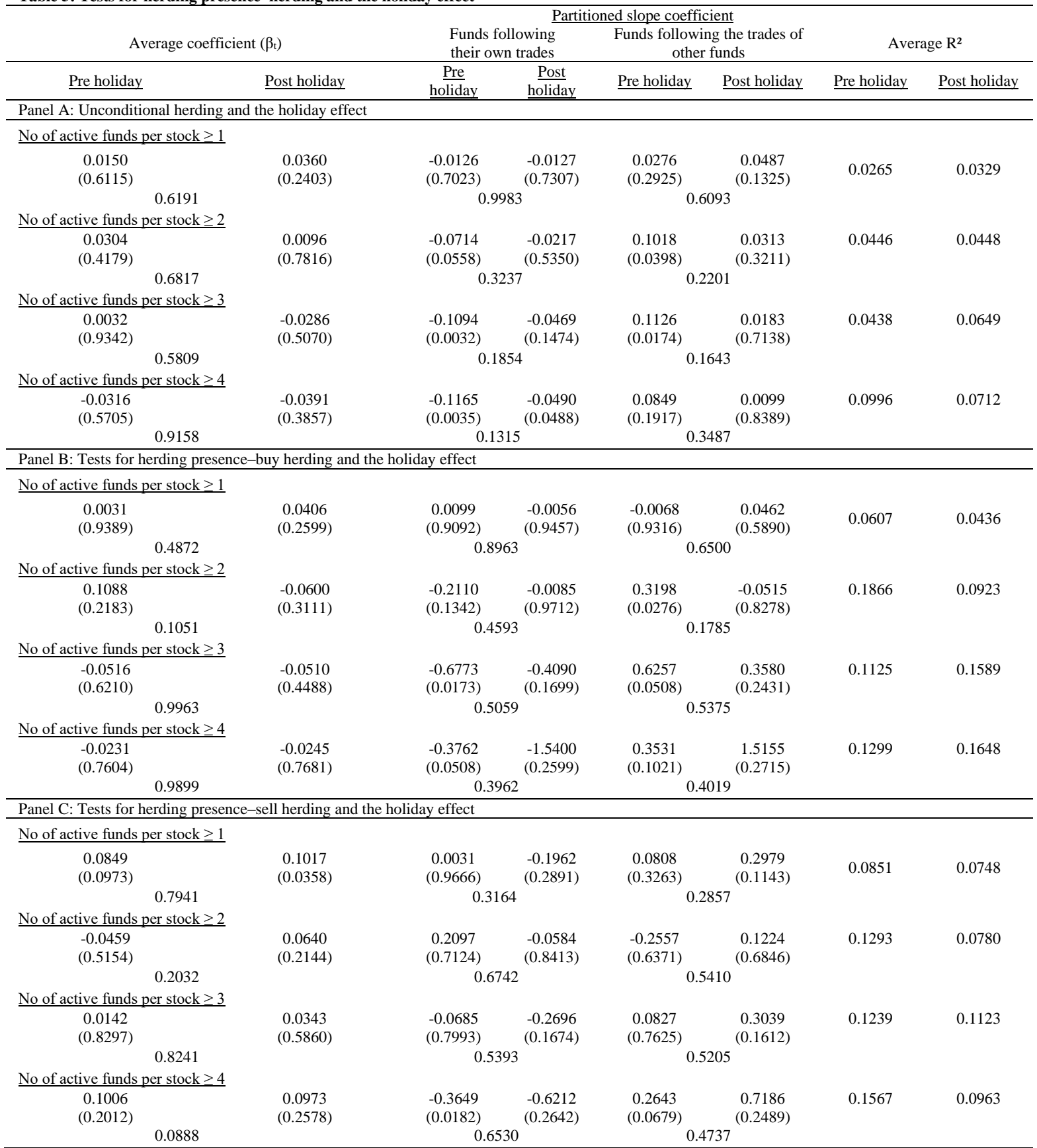

This table reports the estimates from the equation: $\Delta_{\mathrm{k}, \mathrm{t}}=\beta_{\mathrm{t}} \Delta_{\mathrm{k}, \mathrm{t}-1}+\varepsilon_{\mathrm{k}, \mathrm{t}}$ for pre and post holiday days (defined as the day immediately preceding and the day immediately after a holiday, respectively) for the full sample of stocks (Panel A), for stocks predominantly bought (i.e. for stocks whose $\operatorname{Raw} \Delta_{\mathrm{k}, \mathrm{t}}>0.5$; Panel B) and for stocks predominantly sold (i.e. for stocks whose $\operatorname{Raw} \Delta_{\mathrm{k}, \mathrm{t}}<0.5$; Panel C). For each security and day between January, $2^{\text {nd }} 2002$ and August $14^{\text {th }}, 2008$ we calculate the fraction of funds that increase their position in the security. A fund is defined as increasing its position if it holds a greater fraction of the firm's shares at the end of day $t$ than it held at the end of day $t$ - 1 . All data are standardized (i.e. rescaled to zero mean, unit variance) each day for pre and post holiday days. We then estimate daily cross sectional regressions of institutional demand on lagged institutional demand once for the pre holiday and once for the post holiday days only for the full sample of stocks (Panel A), stocks predominantly bought (Panel B) and stocks predominantly sold (Panel C). Because $\Delta_{\mathrm{k}, \mathrm{t}-1}$ is the sole independent variable in each regression and the data are standardized, these regression coefficients are also the cross sectional correlations between institutional demand and lagged institutional demand for that sample pre and post holiday, respectively. The first column reports the time-series' average of these correlation coefficients and associated p-values (in parentheses) pre and post holiday. The second and third columns report the portion of the correlation resulting from funds following their own lagged trades and the portion resulting from funds following the previous trades of other funds (herding) for each of the two days. P-values of Wald test-statistics of difference between pre and post holiday estimates are included underneath each pair of estimates. 
Table 6: Tests for herding presence-herding and the Ramadan effect

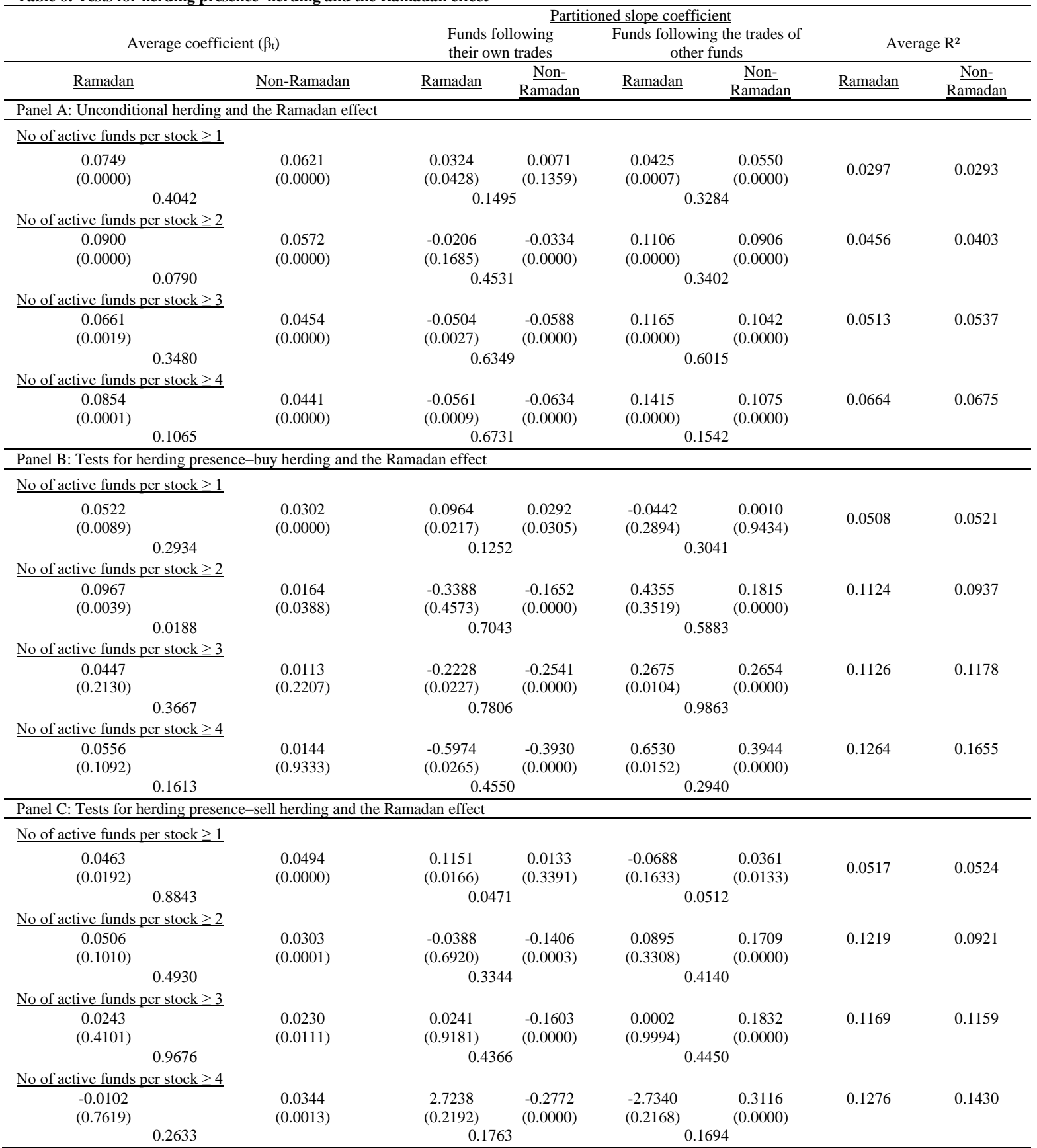

This table reports the estimates from the equation: $\Delta_{\mathrm{k}, \mathrm{t}}=\beta_{\mathrm{t}} \Delta_{\mathrm{k}, \mathrm{t}-1}+\varepsilon_{\mathrm{k}, \mathrm{t}}$ within and outside the month of Ramadan for the full sample of stocks (Panel A), for stocks predominantly bought (i.e. for stocks whose $R a w \Delta_{\mathrm{k}, \mathrm{t}}>0.5$; Panel B) and for stocks predominantly sold (i.e. for stocks whose $R a w \Delta_{\mathrm{k}, \mathrm{t}}<0.5$; Panel C). For each security and day between January, $2^{\text {nd }} 2002$ and August $14^{\text {th }}, 2008$ we calculate the fraction of funds that increase their position in the security. A fund is defined as increasing its position if it holds a greater fraction of the firm's shares at the end of day $t$ than it held at the end of day $t-1$. All data are standardized (i.e. rescaled to zero mean, unit variance) each day within and outside Ramadan. We then estimate daily cross sectional regressions of institutional demand on lagged institutional demand within and outside Ramadan for the full sample of stocks (Panel A), stocks predominantly bought (Panel B) and stocks predominantly sold (Panel C). Because $\Delta_{\mathrm{k}, \mathrm{t}-1}$ is the sole independent variable in each regression and the data are standardized, these regression coefficients are also the cross sectional correlations between institutional demand and lagged institutional demand within and outside Ramadan, respectively. The first column reports the time-series' average of these correlation coefficients and associated p-values (in parentheses) within and outside Ramadan. The second and third columns report the portion of the correlation resulting from funds following their own lagged trades and the portion resulting from funds following the previous trades of other funds (herding) within and outside Ramadan. P-values of Wald test-statistics of difference between within and outside Ramadan estimates are included underneath each pair of estimates. 
Table 7: Tests for herding presence-herding and the sunshine effect

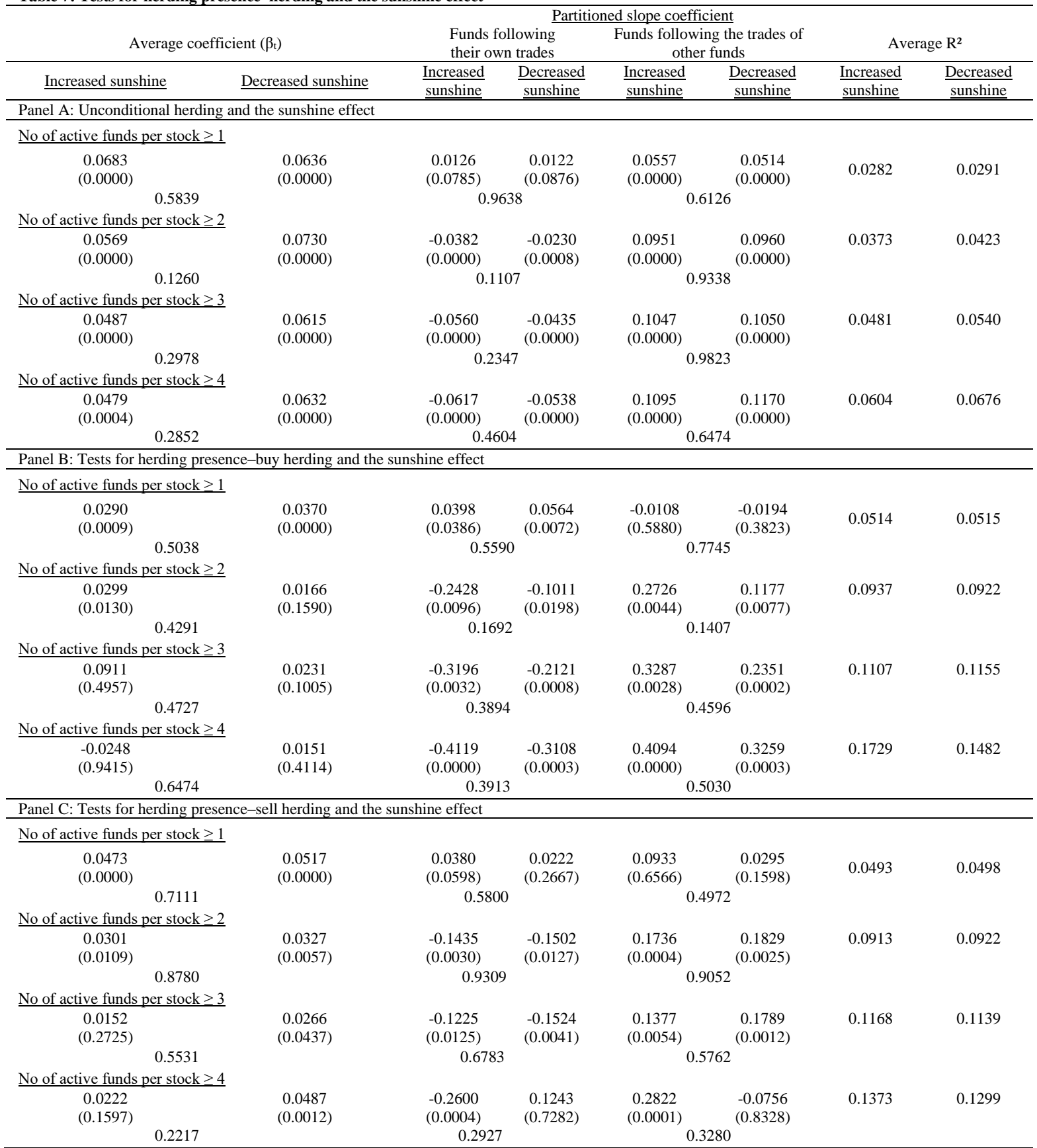

This table reports the estimates from the equation: $\Delta_{\mathrm{k}, \mathrm{t}}=\beta_{\mathrm{t}} \Delta_{\mathrm{k}, \mathrm{t}-1}+\varepsilon_{\mathrm{k}, \mathrm{t}}$ during days of increased and decreased sunshine (having first identified the sunshine hours per day drawing on data obtained from the Turkish State Meteorological Service) for the full sample of stocks (Panel A), stocks predominantly bought (i.e. for stocks whose $R a w \Delta_{\mathrm{k}, \mathrm{t}}>0.5$; Panel B) and stocks predominantly sold (i.e. for stocks whose $R a w \Delta_{\mathrm{k}, \mathrm{t}}<0.5$; Panel C). For each security and day between January, $2^{\text {nd }} 2002$ and August $14^{\text {th }}, 2008$ we calculate the fraction of funds that increase their position in the security. A fund is defined as increasing its position if it holds a greater fraction of the firm's shares at the end of day $t$ than it held at the end of day $t$ - 1 . All data are standardized (i.e. rescaled to zero mean, unit variance) each day for increased/decreased sunshine days. We then estimate daily cross sectional regressions of institutional demand on lagged institutional demand for increased and decreased sunshine days for the full sample of stocks (Panel A), stocks predominantly bought (Panel B) and stocks predominantly sold (Panel C). Because $\Delta_{\mathrm{k}, \mathrm{t}-1}$ is the sole independent variable in each regression and the data are standardized, these regression coefficients are also the cross sectional correlations between institutional demand and lagged institutional demand for increased and decreased sunshine days, respectively. The first column reports the time-series' average of these correlation coefficients and associated p-values (in parentheses) for increased and decreased sunshine days. The second and third columns report the portion of the correlation resulting from funds following their own lagged trades and the portion resulting from funds following the previous trades of other funds (herding) for increased and decreased sunshine days. P-values of Wald test-statistics of difference between increased and decreased sunshine days' estimates are included underneath each pair of estimates. 